\title{
The Different Meanings of Land in the Age of Neoliberalism: Theoretical Reflections on Commons and Resilience Grabbing from a Social Anthropological Perspective
}

\author{
Tobias Haller $(\mathbb{D}$ \\ Institute of Social Anthropology, University of Bern, 3000 Berne, Switzerland; haller@anthro.unibe.ch
}

Received: 5 May 2019; Accepted: 24 June 2019; Published: 27 June 2019

\begin{abstract}
Recent debates in social anthropology on land acquisitions highlight the need to go further back in history in order to analyse their impacts on local livelihoods. The debate over the commons in economic and ecological anthropology helps us understand some of today's dynamics by looking at precolonial common property institutions and the way they were transformed by Western colonization to state property and then, later in the age of neoliberalism, to privatization and open access. This paper focuses on Africa and refers to the work of critical scholars who show that traditional land tenure was misinterpreted as customary tenure without full property rights, while a broader literature on the commons shows that common-pool resources (pasture, fisheries, wildlife, forestry etc.) have been effectively managed by locally-developed common property institutions. This misinterpretation continues to function as a legacy in both juridical and popular senses. Moreover, the transformation of political systems and the notion of customary land tenure produced effects of central importance for today's investment context. During colonial times a policy of indirect rule based on new elites was created to manage customary lands of so-called native groups who could use the land as long as it was of no value to the state. However, this land formally remained in the hands of the state, which also claimed to manage common-pool resources through state institutions. The neoliberal policies that are now demanded by donor agencies have had two consequences for land and land-related common-pool resources. On the one hand, states often lack the financial means to enforce their own natural resource legislation and this has led to de facto open access. On the other hand, land legally fragmented from its common-pool resources has been transformed from state to private property. This has enabled new elites and foreign investors to claim private property on formerly commonly-held land, which also leads to the loss of access to land related common-pool resources for more marginal local actors. Thus, the paper argues that this process does not just lead to land grabbing but to commons grabbing as well. This has furthermore undermined the resilience and adaptive capacity of local populations because access to common-pool resources is vital for the livelihoods of more marginal groups, especially in times of crisis. Comparative studies undertaken on floodplains in Botswana, Cameroon, Mali, Tanzania and Zambia based on a New Institutional Political Ecology (NIPE) approach illustrate this process and its impacts and show how institutional transformations are key to understanding the impacts of large-scale land acquisitions (LSLA) and investments in Africa.
\end{abstract}

Keywords: land grabbing; institutions; common-pool resources; common property; land tenure transformations; resilience, social anthropology 


\section{Introduction}

This paper tries to reach a conclusion about issues that theoretically seem to relate only in a very loose way: Resilience is, on the one hand, defined as the capacity to absorb shocks and perturbations of social-ecological systems and show their adaptability and transformation capacity often related to a natural hazard and climate change (see Folke et al., 2010) [1]. On the other hand, new debates in the social sciences and humanities on land, ecosystems and natural resource managements argue that it is political constellations that undermine the resilience of local actors [2,3]. The latter is related to critical perspectives in political ecology and ecological anthropology that have triggered new meanings about land and land use generally and, in particular, in Sub-Saharan Africa. This region is the geographical and empirical focus of this paper, which makes the following basic argument: Institutional change from resource-interrelated common property institutions to fragmented state and then private property and open access developments leads to commons grabbing for local people. It furthermore creates an institutional pluralism from which local elites formed during colonial times can profit because they can select the private property options after the undermining of state property during the implementation of neoliberal privatization policies driven by donor agencies [2,3]. These processes do not just lead to commons grabbing; they also undermine the adaptive capacity of local people to enhance their resilience, and this is the connection, which has not been made in the literature up to now and that combines the two strands. I thus argue as a theoretical part of this special issue that commons grabbing will also reduce the adaptive capacity of people in social-ecological systems and are thus to be seen as resilience grabbing processes.

These processes have often not been recognised in LSLA settings in Africa, because companies collaborate with local elites and with the state.

My interest in land issues grew from a political ecology perspective in the context of African crises that were prevalent in the 1970s, and which were repeated in hunger crises in the 1980s, 1990s, and 2000s up and continue to the present time. Many of the issues labelled as hunger and underdevelopment, with the added complication of climate change, have been presented as 'home made' African issues in development studies. These have repeatedly focused on neo-Malthusian, technology-based views and on narrowly conceptualized neoclassical ideas (see Timberlake's 1985 Africa in Crisis as one of the most cited examples). Counter-arguments have been manifold. Perhaps the most important theoretical strands were neo-Marxist, and local and global political ecology (Robbins 2005 [2], Peet, Robbins, Watts 2011 [3]) lines of argumentation that advocated colonial and market-specific legacies as reasons for the ongoing crises.

Another strand dealt with the way Africa and African development is perceived from the development perspective of the Global North. James Ferguson's image of the Anti-Politics Machine focused on Lesotho's development problems, which were labelled as problems of an independent state during the Apartheid era. It became evident, however, that Lesotho experienced almost the same level of dependence as the Bantustans, which were under South African control during the time of Apartheid. Thus, the Anti-Politics Machine was hiding the asymmetric power relation behind the notion of development (Ferguson 1994) [4]. This finding led to a political economy lens being used to look at development issues in Africa in general. On the one hand it might be polemic to view all African nations as being like the Bantustans, but on the other, there is some basic truth in the concept of the anti-politics machine: Discourses on development in Africa hide underlying political and economic interests (or disinterests). But what are these economic interests? Who pushes them? And what is at stake? Is it just globalized neoliberalism that sets the stage by labelling Africa in a specific way (see also Ferguson's 1999 Global Shadows) [5] or are additional issues involved?

It is interesting to see what labels are being used at the present time in this regarding Africa. While daily political media are full of new versions of the doomed continent, with a recent shift in focus from ethnic wars, under-development and environmental degradation to issues regarding climate change and terrorism (and lately the Ebola virus); economic journals, reports and analyses are enthusing over the new boom in African economies. The latter focus on high GDP growth rates, marvellous 
investment opportunities in mining, oil and land as well as, increasingly, in IT and other industries. In addition, it is said that education is improving, poverty is being reduced and demography-now suddenly a good thing-is rising: Africa enables the Fastest Billion "(as Charles Roberson's 2012 book title promises) [6] through foreign investment, if "done in the right way".

One area where Africa has seen much investment is in land. The literature on Large Scale Land Acquisitions (LSLA) and investments or land grabbing is growing, especially in the resurrected Journal of Peasant Studies. Several authors with at least three major theoretical orientations have been setting the scene, (a) outlining opportunities and documenting collateral damage caused by investments (Deininger 2011) [7]; (b) by adopting a critical political economy position, arguing that there will be more losers than winners (de Schutter 2011 [8], Hall 2011 [9], Cotula 2013 [10]); and (c) a (rather marginal) Neo-Marxist position. The latter seems to follow Harvey's A Brief History of Neoliberalism (2007) [11], seeing large-scale agricultural investments or land grabbing as part of "primitive accumulation" processes by which the agricultural producers will form an agrarian proletariat (see Basu 2007) [12]. There is a significant body of newer literature (see the Journal of Peasant Studies since 2011), which unfortunately rarely includes in-depth field studies or emic views of actors in this field (see critiques by Oya 2013, and Lanz, Gerber and Haller 2018) [13,14].

However, organizations such as ILC, IIED Oxfam and Justica Ambiental provide more in-depth case studies, and there are some rare overviews such as the one by German, Schoneveld and Pacheco (2011) [15]. These do not, however, provide much data from the emic perspectives based on the longer periods of fieldwork that characterize social anthropological research. Unfortunately, social anthropology has been rather silent on these issues apart from some overviews (see Li 2011 [16] on labor issues, and Fairhead, Leach and Scoones 2012 [17] on green grabbing). However, these papers do not often provide concrete insights into LSLAs or land grabbing processes over a longer period of time, which could indicate changing constellations of actors, how their decision making unfolds and what strategic actions they are taking. Human geographers Locher and Sulle, writing about a Tanzanian case study, are a noteworthy exception [18]. Therefore, a combined institutionalist and political ecology view on this topic might be helpful, particularly regarding new institutionalist approaches that discuss land issues in the context of changing rights and obligations. Of course, the actual actors' perceptions cannot be neglected. The main question is how deals covering land and related resource rights are perceived by local actors as these have been changing since precolonial times. This requires an approach that focusses on how land and land-related common-pool resources are perceived in a changing world in relation to the bargaining power of involved actors and discourses they use to legitimate their actions: New institutionalism in social anthropology provides an analytical tool for these issues and links them to external historical change.

\section{Land and New Institutionalism in Social Anthropology}

Land has been a research preoccupation of social anthropologists since the colonial era, and has intensified with more recent land grabbing debates not only in African contexts, in which the land grabbing debate is most prominent, but as well in Asia and Latin America. What was perceived as land from a colonial perspective differed much from local views on what land meant. The colonial gaze made landscapes a wild, uncivilized and at best underused resource, which did not correspond with the local views on what land meant. However, many social anthropologists were caught in a dilemma. On the one hand, differences in perception between the local and the colonial actors became evident and asked for cultural translations while on the other hand, the colonial contexts, in which anthropologists were working in the Colonial era put them in a position of being collaborators or at best informants $[5,19]$. In Latin America, these issues were linked to the eviction of local groups and their marginalization as these views where not perceived by the colonial powers as being relevant land claims (see Wolf 1983 [19] for a general overview, Stocks 2005 [20]). In Africa, as well in parts of Asia, local people partially remained on their territory, but also faced evictions. Still, large portions of areas 
in Africa were labelled customary land (see Chanock 1991 [21], Peters 2013 [22] for Africa, Li 2011 [16] for Asia).

Colonial developments in Latin America started much earlier and led to debates over frontier zones. On the colonized side of the frontier, large parts of land were allocated to private land-owners through the Spanish or Portuguese crown, which were later claimed by the elites of the emerging states. Behind the frontier, often in rainforest areas, a constant colonialism process occurred that is still going on today Millington (2018) [23] for Bolivia. The original inhabitants were given reserves and gained some rights as indigenous peoples after an extremely harsh process of expulsion and physical partial elimination (see Bodley 1985) [24]. And despite political recognition of indigenous peoples, the debate that these small groups have rights to too much land is ongoing (see Stocks 2005) [20]. In Asia, similar processes unfold with the exception of India and China (see Geiger ed. 2008) [25], Li 2014 [26]). Nevertheless, indigeneity is a political tool these groups can use to defend their land (see also Galvin and Haller eds. 2008) [27]. In contrast, I will now focus on African contexts for the rest of this paper as most large-scale land acquisitions take place there and because the issues on the African continent differ significantly from Latin America and Asia as the political notion of indigeneity is difficult to be applied in Africa.

While colonialization processes in the African context were also not uniform, there are some similarities between the British and the French control as well as the Lusophone colonial and the pre-WWI German contexts (see Mamdani 1996: 80ff.) [28]. A globalized view of European expansion indicates that colonizing Africa in order to use both the land and the work force made much more sense than colonizing the land without the people. Land is only valuable when made valuable by external view. This was the case at the beginning of colonial times in Africa in the context of low mechanization. The fact that the colonial process was one not so much of economic profit but of high costs did not really matter in the beginning. What mattered was the initial idea of getting minerals and putting virgin land to use-and this view held sway in the minds of administrators despite the fact that people were living on the virgin land. The label of customary land was created in colonial times, based on evolutionist views of land institutions (from free to commons to private property) developed in this initial phase of colonisation. British colonial indirect rule became the blueprint, and outsourcing the management and control over land and people to select local authorities called chiefs was part of this model (Mamdani 1996 [28]., see also Haller ed. 2010 [29], Haller 2013 [30]). In many areas studied and compared, precolonial power structures included politically egalitarian, segmentary lineage groups, big-men structures (leading rivalling men) or more hierarchical groups. The institution of chief was often a colonial creation installed by the European authorities and especially undermined the egalitarian and big-men power structures [29]. These chiefs then commanded a specific territory of a so-called tribe. In this naturalization process of African land governance systems, it was emphasized that resources were communal. Therefore, there was no notion of real property. Peters outlines this by referring to Iliffe as follows:

The imposition of customary tenure with its denial of full ownership rights to land-holders had several key effects. One was to halt development of a land market by ignoring or denying evidence of past transfers, and by declaring that land was inalienable "according to tradition". Another, by placing land management under the institution of chieftaincy (though ultimately under the colonial state), intensified competition among the various incumbents of traditional leadership roles and centred that competition on land. The fixing of territorial boundaries over which the traditional authorities were made trustees greatly reinforced the link between political authority and authority over land. (Peters 2013, pp. 3-4) [22]

Many examples from African colonies provide evidence that the British tried to implement indirect rule, as did the French in practice-in contradiction to their direct rule policy (see Mamdani 1996) [28]. Despite the many differences over the continent, this led to the functioning of a cheaper management structure, never allowing full ownership at the local level (by chiefs) but which kept ultimate control over ultimate land ownership. As a consequence, this transformation fuelled local conflicts by inciting 
competition between installed chiefs and other elites. This is illustrated by Firmin-Sellers [31] and case studies from Mali, Cameroon, Tanzania, Zambia and Botswana where there is a common shift in chiefly authority over land [29]. Therefore, customary property was a camouflage of a wrong labelling of traditional property systems in which land was said to be (a) not for sale; (b) not related to individual views of belonging; and (c) commonly owned and therefore not property as such. This colonial narrative was upheld and supported a discourse on modernization processes in agricultural development: Common property tenure is perceived as a hindrance to development, despite the fact that during and after colonial times-with and without force-local peasant smallholders were producing cash crops for the market (see Netting 1993 [32], Peters 2013 [22]). Nevertheless, it was not just an increasing population that gave rise to competition over land since the 1970s but also increasing pressure on reduced land due to growing, multiple interests by the introduction of new agricultural production methods, mining and through the institutionalization of protected areas (game and forest reserves, see Neumann 1998 [33], Haller 2013 [30]).

The intensification of land use and land-related resources worldwide, highlighted by repeated hunger crises in the Sahel zone, created the image of land being degraded due to the overuse of natural resources held in common. This triggered a debate on the relationships between land and property not just from an economic angle but from an ecological point of view as well. Reference was made to Hardin's Tragedy of the Commons (1968) [34]. In this essay, which had no empirical evidence but was a Neo-Malthusian polemic against the freedom of human population growth, Hardin did not want to deal with land issues per se. He painted a picture of pastoralism in which actors are only interested in increasing their herd size illustrating the process of freedom in reproduction (here of cattle and then more generally of people) as degrading the pasture because it is governed as common, not private, property (see Acheson 1989 [35], Ostrom 1990 [36], Haller 2007a [37]). This had a strong effect on state policies, especially in supporting justifications of states to control natural resources within their boundaries and it was a welcome ideological legitimacy for stricter state governance and later for neoliberal privatization policies (see Feeney et al., 1990 [38], Fairhead and Leach 1996 [39]).

The arguments picked up by mainstream science and by governments regarding the economic and ecological flaws of traditional land tenure triggered a process of revision and rethinking. This was led by Elinor Ostrom, who devoted her Nobel Prize winning work to craft a new picture of common-pool resource management in common property regimes [36]. The main argument was that renewable common-pool resources, which are subtractable (what is taken away cannot be used by others for the moment) and difficult to defend (but possible by a group that can organize collectively), could be managed in a sustainable way by so-called robust common property institutions. Foremost, she and other scholars highlighted that Hardin erred in his view on the commons as open access but that resources held in common property regimes are the property of a group and not no one's property. Eight design principles for well-working institutions in her book Governing the Commons (1990) [36] were deducted from (mostly) social anthropological case studies. They indicated that institutions address the problem of freedom and free riding by reducing transaction costs (information, monitoring and sanctioning). Ostrom's work related to environmental issues, and it followed the line of argument of new institutionalism on property rights proposed by Douglass North (1990) [40], who in fact had followed Roland Coase's theory on the firm and labour contracts to illustrate that institutions do reduce transaction costs. The amount of work emanating from Ostrom's approach to new institutionalism as related to the commons is immense. There is now a digital library of the commons as well as journals linked directly to the issue. This is proof of the broad scholarly interest and is also manifest in growing participation in the International Association for the Study of the Commons (IASC), previously named the International Association for the Study of Common Property.

However, some variables that the economic historian Douglass North had integrated in his model such as power relations, were missing in Ostrom's work. She was more concerned with the possibility of self-organization and sustainable use of common-pool resources and neglected historical embedment or issues of politics and of power. Despite the recognition that institutions are also embedded in 
larger systems, her primary focus was thus not multilayered in the sense that, viewed from a political economic and ecological stance, local systems are often not articulated but still power-related parts of state constitutions, legal systems and state elites as well as of international global governance regimes and global markets (see Haller 2007a [37], 2007b [41]. While studies focusing on the way self-organization is made possible as a puzzle stemming from game theory, a new approach from social anthropology emerged [42]. Starting from models in economic anthropology, Jean Ensminger (1992) [43], a US social anthropologist, proposed an interrelated model in which external factors (environment, population and technology) lead to changes in relative prices of goods and services and had a local impact (Figure 1).

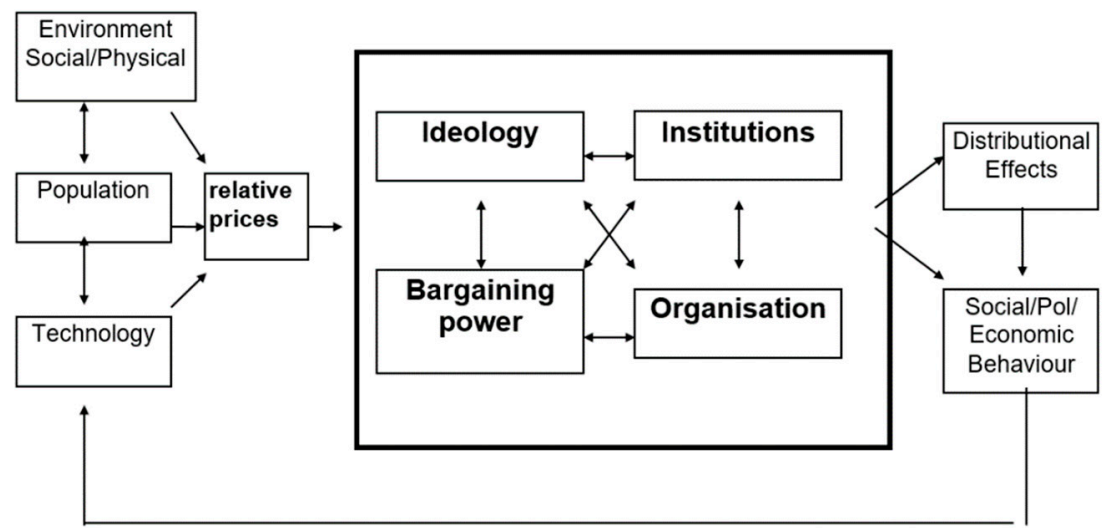

Figure 1. Modelling institutional change. Source: Jean Ensminger (Ensminger 192, p. 10) [43].

Local contexts (in the model bargaining power, institutions, ideology and organisation) are influenced by the changing relative prices and relative value that a specific resource or a region is gaining. In line with the work of North [40], Ensminger argues that the bargaining power of actors, the way they organize and the way they select and craft institutions and legitimate this by ideologies impacts the distribution, use and finally reproduction of resources in the environment, population and technology, i.e., the feedback loops in Figure 1. Therefore, in line with North she does not follow other New Institutionalism economists who predict that the market will choose the optimal institutions (see Williamson 1987 [44]). Rather, institutional settings and, later, distribution are shaped by bargaining power and ideology as a resource of legitimacy. This means that, for example, a rise in the relative price of land will not automatically trigger immediate privatization but can have different outcomes depending on the bargaining power of actors and the way they are able to produce legitimacy (ideology) for their choice of a certain institutional option. This model has been enlarged, looking closely at issues of bargaining power and ideology (including constructivist approaches regarding discourse and narrative to produce legitimacy, often in either so called traditional or modernization ideologies $[29,30])$.

This point will be taken up later in this article as I return to the issue of land and the colonial and postcolonial discontinuity. But how are these issues related to land, to LSLAs or land grabbing? The theoretical focus on common-pool resources could direct the view that land is a general category, linked to the territory of a group of users including multiple resources without specifying the way the land and its resources are used. This is often ignored, and the focus is on how property rights on land alone are defined from an outside point of view of the state and its actors. Hence, there is a paradox: On the one hand, land as agricultural land or soil is often separated from resources other than soil, while on the other hand land-related common-pool resources are ignored as if these would not matter for local people and their livelihoods and is only perceived as pure nature [29,30,33,39]. In legal terms, land becomes a category of its own, separated from all interrelated resources. While water continues to be seen as an additional and necessary resource for commercial agricultural production, all other resources and the way they are interconnected are no longer of interest, be they pasture, 
fisheries, wildlife, veldt productions, etc. However, from an emic view (local socio-cultural perspective), land might mean something very different as I will try to show based on the research conducted by a team involving three MA and three doctoral students and a postdoctoral researcher in areas of six African floodplains in Mali, Cameroon, Tanzania, Zambia and Botswana between 2002 and 2008 funded by the Swiss National Science foundation ([29,30,45]).

\section{Elements of Emic Perceptions of Land: Insights from Research in African Floodplains}

Several authors emphasize that the precolonial notion of land in Africa was shaped by numerous factors, which involve tenure systems, type of land use and what identities land generates. They argue that from a local (emic) perspective land was not based on the notion of state and market-related private property. Instead, it was always considered as a mixture of private and communal property under the governance of leading offices (e.g., elders, specialists) in more politically symmetrical situations or through leaders from more asymmetrically powerful groups. And it was related to so-called first settlement of such groups or as a consequence of the conquest of feudal or more powerful systems (see Benjaminsen and Lund 2003 [46], Toulmin 2008 [47], Peters 2013 [22]). These authors then argue that the "traditional tenure systems" we see today do no longer represent precolonial tenure but are mostly the result of imposed colonial transformations of property rights labelled "customary law" (see Chanock 2005).

The aim of this paper is not to provide a literature review on this issue as this has been done elsewhere ([28-31]) but to show insights from a research project called The African Floodplain Wetlands Project (AFWeP) conducted by our team that introduces some interesting elements of emic views on land in six floodplain regions in Africa (see Haller ed. 2010) [29]. These cases are of interest in the context of this paper as comparative research was based on long-term anthropological fieldwork, including participant observation, oral histories and biographies in order to understand the emic view. The team combined literature and archival research with oral history on precolonial institutions for the management of common-pool resources and produced results for the:

1. Inner Niger delta, Mali (different fishing communities, agricultural groups, Fulbe)

2. Waza-Logone floodplain, Cameroon (Kotoko fishing communities with a Sultan, immigrant Mousgoum agriculturalists, Fulbe and Arab Choa pastoralists)

3. Pangani floodpain, Tanzania (Pare-Peasant and Maasai pastoralists)

4. Rufiji floodplain, Tanzania (local hunter-gatherer, fishing and farming communities)

5. Kafue Flats floodplain, Zambia (hunting-gathering, agro-pastoralists of Ila, immigrated Lozi and Tonga)

6. Panhandle/Okavango Delta, Botswana (different hunter-gatherer groups, cattle, later on agriculture).

Regarding the emic perception of land in precolonial times, this research revealed that the category land is embedded in views of territory and landscape with all its resources, which are perceived as being interconnected and used for securing economic and political existence. People were concerned with a secure livelihood, as well as the political security that an area with all its resources provided. Four issues are of importance to understand what land means through this lens: (1) first-comer-late-comer relations; (2) coordinated and reciprocal use of common-pool resources and related to this; (3) spiritual landscape relations; and 4) emerging institutions for common-pool resource management (see also Haller 2019 [48]):

1. As in the cases referred to by Lenz (2006) [49] and Toulmin (2008) [47], political differentiation regarding resources and territories was based on the distinction between so-called first-comers, mainly but not always hunter-gatherer or fishing communities, and late-comers, such as agricultural and pastoral groups. Land in the narrow sense was just one aspect of something emically called an area (or a territory) with many resources. First-comers did not use all the resources, while late-comers often used other niches, leading to increased ethnic specialization in 
some cases (case studies 1-4) or by using the whole set of resources (case studies 5 and 6 which is a process that developed later on also in the other cases.

2. In order to mitigate economic and political risks, reciprocal resource use took place within and between people of different territories. For example, the different agropastoral subgroups of the Ila on the Kafue Flats (case study 5) had agreed upon mutually beneficial arrangements for access to fishing and hunting areas since sharing these resources reduced the risk of low catches.

3. Regarding territory tenure or property, so-called first-comers did not see themselves as "owners of the land". Instead, they saw themselves as the ones who established first contact with supernatural powers that could-if not respected-transform elements of the environment in negative ways (e.g., through drought, sickness, wild animal attacks). Often these supernatural powers were seen as spirits in the water, in the land (soil) or related to animals. Some spirits had human counterparts, so called ritual specialists, with whom they communicated regarding offerings. From the emic perception this is seen as a kind of reciprocal arrangement of give-and-take based on the notion that spirits are the actual owners and that one is not alone in the territory. Another level is made up of the ancestral spirits who grant the use of the landscapes with their multiple interrelated resources. The interaction with these powers controlling the landscapes is organized via rituals and related offerings in order to make and renew spiritual contracts on the landscape. Leaders were those first-comers who had a link to the spirits themselves or who had ritual specialists who did.

4. These leaders and specialists thus held offices of great importance and interest. They also coordinated resource use by other members of the communities as well as of late-comers who were then dependent on them. This was often based on a clear notion of seasonal availability of resources. Where no conquest took place, institutions in the form of reciprocal arrangements with neighbouring groups were common. The territory with its multiple and interconnected resources such as soil, water, pasture, wildlife and fisheries, was used in a coordinated way based on these emerging co-created institutions. In some cases, long-term agricultural production and use could develop into a kind of family property of land due to the length of time it had been used and the investments that had been made. However, the other resources of these small territories could still be used by all members of the community during the different seasons (e.g., a harvested field can become a pasture that others use). Most importantly, the territory could be given to someone else for use after negotiations. Different institutional arrangements in floodplain areas refer to groups and leaders who are responsible for complex resource use coordination, especially in floodplains where there are big differences in seasonal resource availability. Adaptation to seasonality was one driving force; others were conflict and conflict resolution. For example, the institutions established for the use of pasture, wildlife, fisheries and land use in the Kafue Flats (Case study 5) were often established after conflicts had occurred. They are based on myths and oral history but still remember and actively contribute to the establishment of a complex governance system that is working well.

The case studies also show that there is a peculiar mixture of economic rationale and power specific justification to institutional arrangements. In addition, they are combined with ecological adaptive features, fitting into the seasonal flood water advance and retreat. First-comers and more powerful late-comers tried to legitimize their presence via symbolic interaction with the supernatural beings living in the landscape as a whole or in important parts of the landscape, (e.g., on land or in water), but these spirits have further implications if not heeded. Interestingly, more powerful groups that arrived later in an area tried to marry into first-comer families or to link up with the spiritual world of the latter. Therefore, land is just one part of a belief system. In this system, people see their economic and political well-being as a central focal point which is linked to the spiritual world in relation to the environment. Regardless of differences in political systems (whether segmentary, constructed around 'big men' or hierarchical), the locally-developed models show similar forms. 
It is also evident that these first-comers and late-comers were trying to find arrangements with the aim of achieving economic security and political gains for the leaders themselves. This aspect can be illustrated in the case of the Kafue Flats fisheries (case study 5). There, the Ila late-comers married into the Batwa first-comer fishing communities and established a notion of spiritual ownership over ponds via ancestral links. These ponds are filled with water and fish during the rainy and flooding seasons. To coordinate the use of fish and to prevent free-riding, collective fishing days are agreed upon by leaders and their spiritual masters, allowing all members of the community access to fish since it is a communal resource. Fishing activities are allowed only after rituals for ancestral sprits are completed. Before the rituals and after the fishing days, fishing is not allowed in the ponds anymore. This rule is monitored and sanctioned twofold: There are patrols, and there are fines for those disregarding the dates set by community leaders. In addition, there is a monitoring institution embedded in the belief system itself. People link ancestral spirits to crocodiles that are found in the ponds after having left the main river after floods. Not to submit oneself to the rule of coordinated use after a ritual has been carried out will lead to attacks by ancestral spirits via crocodiles. This functions as a kind of supernatural sanction. There are also clear rules concerning fishing techniques based on gender differences (spears for men, baskets for women). Reciprocity in the use of the ponds is furthered by issuing invitations to members of other communities [30,50,51].

This last point is central to the study. We discovered that local groups have a clear notion of boundaries and territories, but these notions include an idea of permeability and flexibility of boundaries. This can be seen as a way to reduce risks resulting from variability in flooding patterns and consequent availability of resources. Therefore, institutions, which include notions of flexibility of use, reduce risks and fulfil an important economic aspect inherent in the general principle of minimax-strategies. However, such a way of coordinating resource governance also make sense politically as alliances are possible, theft is reduced and, most importantly, the prestige of local administrators as distributers of resources is enhanced. This is clearly the case with the Kafue Flats fisheries example but also in other instances (see cases in Cameroon (Fokou 2010 [52]), and Tanzania (Meroka 2010 [53])).

This leads us to encourage further studies in this direction. At the same time, a preliminary conclusion can be proposed. From an emic ontology and epistemology, land is part of a larger, symbolically viewed complex of cultural landscapes inhabited by spiritual beings that influence production and consumption for people, arriving at various stages in time and therefore occupying different (hierarchical) identities in this interaction. Moreover, the different resources that we view separately as outsiders are closely interconnected. This is also reflected in the institutions that often play the role of a coordinating body between the different, interconnected uses. For example, in the Waza Logone floodplain (case study 2) fisheries, agricultural practices and pastoralism have to be coordinated so as not to conflict with one another. Conflicts cannot be ruled out completely, but institutions often emerge out of conflicts as a result of conflict-resolution mechanisms. Institutions are also flexible and can be renegotiated if they do not fit a specific problem or are questioned by more powerful groups: This is a highly interesting aspect. Institutions are often the result of different bargaining power constellations. The most powerful does not simply win but has to engage in a compromise with the less powerful in order to reduce resistance that is economically not viable. More powerful people can of course devise rules that are in their interest alone but will face resistance at high costs from other users as common-pool resources are not easily defended. Therefore, it is better to share and to establish a legitimized distribution. For example, hunting institutions in the Kafue Flats illustrate this point $[30,50,51]$.

This shows that if we focus only on land we miss all the other resource contexts and regulations in which the land question is embedded. Specifically, poorer resource users (but not just poorer resource users alone) do not only use the land. They also use the related common-pool resources and institutions that are organized around this multiple use and depend on these more than the richer resources users in order to make a living. 
What does this mean, especially in the context of recent literature on land and identities by Benjaminsen and Lund eds. (2003) [46], Kuba and Lenz eds. (2006) [54], Derman et al. (2007) [55]? We see this literature not as a contradiction, but as a contribution to a better understanding of hitherto misread customary "systems in Africa". We strongly claim that land is a political issue in Africa, but we also argue that we need a more complex perception of landscape areas with multiple uses and users. The hegemonic misreading of land in Africa (see also Fairhead and Leach 1996) [39] has huge resource management and political implications-as we will see later on-that go beyond issues of land per se but include notions of identity and politics of belonging (see Kuba and Lenz eds. 2006) [54]. We will argue that specific issues of belonging are triggered also by external influences on ideologies as outlined in the model of new institutionalism. These have become ways to legitimise inclusion and exclusion in times of externally induced scarcity (Derman et al., 2007) [55] and contestations due to processes of open access and privatization (see for example Chaveau 2006) [56]. This does not contradict the view that during precolonial times access to common-pool resources was negotiated and sometimes unequally distributed (see Derman et al., 2007) [55]. Our studies still show, however, that in this system people with less power were able to get access as well. In addition, and mainly relevant to the discourse on nature conservation, the literature shows that we are not dealing with pure nature but with cultural landscape ecosystems that were created and maintained by the described common property institutions.

Concrete analysis of fisheries, hunting, pasture and rules related to agricultural production in the six case studies reveals that marginal groups also profited from these regulations (e.g., special fishing rights and techniques for women, access to wildlife for the less wealthy, access to pasture on a relatively equal basis, the right to cultivate land in a specific territory). The right to cultivate can also take on the form of more exclusive rights that come close to what could be termed private property. However, these rights did not translate into the right to dispose of the land privately as such decisions about land and land related common-pool resources are vested in larger groups. This means that giving away land was not in the hands of these individuals but was a decision taken by the larger groups and their leaders (e.g., in Kafue Flats although land for cultivation is inherited on the basis of use rights of fathers, leaders still have the possibility to give the land to someone else if needed [30,51].

This refers to the question of formalization of land rights, and in this regard, the dichotomy between formal and informal institutions is rightly criticized in this context (see Cleaver 2007) [57]. On the other hand, local institutions do display certain formalizations. While it is made clear to everyone what basic rules are binding in a specific context, everyday practice might indicate a more flexible way of handling issues; Douglass North would call this informal. I would also argue that institutional bricolage (Cleaver 2002) [57] often happens at the informal level, while bargaining and fixing specific bricolage happens in a more formal arena when rules are revised. Actually, bricolage might not be the right term as it obscures the contested power-specific and strategic notions that are inherent in such processes.

The final issue is the one of legal pluralism that is often cited in the literature (e.g., Benjaminsen and Lund 2003) [46]. Again, based on the six comparative case studies, legal pluralism happens in a precolonial setting. This pluralism is related to the flexibility of local, seasonally-changing resource use requirements and is therefore of a different order than the legal pluralism that we see during colonial and postcolonial times

\section{The Colonial and Postcolonial Disconnect}

In the previous section, I outlined the different views on land from an emic perspective and their implications regarding tenure. This analysis is important in order to understand the impact of colonization on the way land and land related issues are perceived until today. The change brought by colonial administration cannot be underestimated because it was-despite all the differences in national colonial policies and formal procedures-a blueprint leading to legal pluralism and disconnections of another order. 
Looking at Scott's 1998 work on the way that states see resources [58] reveals the basic perspective adopted by the colonial administrations. Paradoxically the state simplifies-as it wants to know what is at stake in order to control it-but at the same time complicates management by separating entities of natural and social order which were originally intertwined. And according to Li (2014) [26] in a critique of Scott's views, it creates messiness. Benjaminsen and Lund are right to argue that this did not just happen with European colonial powers. They cite the example of the Dina -Code in Mali which was introduced by the Fulbe Caliphates in the 19th century. The code regulated and formalized the transhumant use of pasture in the inner Niger delta. Benjaminsen and Lund (2003) [46] do not recognize, however, that this formalization was based on pre-existing institutions regulating and mitigating access not just to pastures but also fisheries and agricultural activities (see Moorehead 1985 [59], Beeler and Frei 2010 [60]). The basic idea was thus different from what the European powers did later. While formalizing some parts of existing regulations and also dealing with them in Islamic courts in the Dina-System, the European Roman, state-related legal system divided resource use and management regulations by treating the interlinked resources under separate and different legal domains. This process was revealed in all the case studies in the AFWeP project (Haller ed. 2010) [29]. It is true that missionaries, trading companies, and later on state administrators and social anthropologists tried to understand precolonial institutions and fit them into a legal system colonial in order to capture and use them. But during the process by which traditional institutions were transformed into so-called customary rights shaped to fit the rights systems of the colonial powers, many issues were misread (see also Benjaminsen and Lund eds. 2003 [46], Berry 1993 [61], Chanock 1985 [62], Moore 1986 [63], Peters 2013 [22]). This process created three levels of pluralism and disconnections.

One is that based on a strategic and single resource-oriented focus during colonial times. Modern Roman law was introduced in areas of central importance for mining and European settler plantation agriculture, while the indirect rule (or direct rule that turned into indirect rule in the French system) was introduced in areas that were less interesting for the state. There, administration was delegated to lower levels of the so-called customary law. Neo-Marxists in social anthropology such as Claude Meillassoux and others argued that these areas were just of interest as a reservoir and recreation territories for cheap labour, to be used elsewhere and then sent back, in order to increase capital accumulation (Meillassoux 1981) [64]. Therefore, even these areas were only of interest as to set up a system that faked local but cheap governance for colonial powers. Thus, a three-layered system was created: written, "traditional" and unwritten. There was the dualism between "modern" European Roman law for land used by the state and by white private owners linked to the colonial and postcolonial state and the "traditional" but state controlled and formalized "customary" laws. The third level was made up of the unwritten rules and norms at the local level, the informal customary rules and regulations, linked to membership of a community or ethnic group $[22,46,65]$ that partially prevailed but, for the most part, was undermined [29].

The second source of pluralism and disconnections refers to the way the state looked at resources in a fragmented way, which then later fitted market, global and neoliberal orders. Colonial and postcolonial states are not different in this regard. While precolonial systems were mostly about a specific territory as a whole landscape, including the living and the dead and mystical powers influencing all elements in a kind of local ecosystem view, the colonial and postcolonial state's view was selectively materially oriented in order to profit from or gain prestige from specific resources. An illustrative case is Tanzania-first a German and then a British colony. Both powers disconnected the landscape from its resources in order to formally use them for different purposes. One division was between white farming and protected areas, with the latter being further divided into forest reserves and game reserves. The forest reserves functioned as areas of timber extraction for the railways; while the game reserves were privileged spots for "sportsman-like hunting", reserved for British nobles and colonial administrators for prestigious habitus-like activities. Protection of such disconnected areas with the focus on just one resource, led to eviction of people and massive transformations 
of these former cultural landscapes. As they turned into bush and became invaded by tsetse flies, the "wild" animals moved out of the reserves and into the fields of the evicted people (see Neumann 1998 [33], Brockington 2003 [66], Meroka and Haller 2008 [67]). Therefore, the legal disconnect during colonial times - the disconnect between land and common-pool resources-became a physical resource disconnect in these former cultural landscapes as water, fisheries, pasture, forestry were used and treated as separate units owned by the state and no longer by the local communities under common property institutions. This process manifests itself in all the case studies in the AFWeP and as well in research elsewhere in Africa (see for example Fairhead and Leach 1996 [38], Brockington 2003 [66]. The AFWeP also concluded that this disconnect was also manifest in the postcolonial administration of natural resources in the floodplains studied.

This leads to a third level of pluralism and disconnection. The states in which the floodplain studies were located (i.e., Mali, Cameroon, Tanzania, Zambia and Botswana) witnessed a massive institutional change during colonial times from common property including the governance of land and land-related common-pool resource to state property. Through this process, common-pool resources were separated legally from the cultural landscape ecosystems created by local people and put them under different departments such as agriculture, fisheries, wildlife, veterinary, water and energy, and tourism. All of these departments based, and still base, their actions on their own legislation and legal settings, leading to a disconnect in management. In Zambia for example, water rights do not consider problems related to fisheries and wildlife, but only look at energy production and irrigation for large-scale plantations (see Haller 2013) [25]. Examples such as this illustrate similar processes in all other countries and regions studied. Such disconnections also produce strife on different levels, not only creating conflicts between resource users, but also lead to different administrative units competing with each other. Again, the case of the Kafue Flats is illustrative. Here, wildlife and fishery departments are creating a conflicting plural setting for resource users as both departments claim authority over, for example, a protected area due to the presence of both fish and wildlife. As both these common-pool resources migrate due to flooding and floodwater retreat on the floodplain, management is complicated and neither local users nor state administrators really know who is in charge or which institutions to adhere too (see Haller 2013 [30]). This problem has also been studied in Southern Africa in the DARMA (Defragmenting Resource Management) Project led Mafaniso Hara and colleagues at the University of Western Cape (see Mlanga et al., 2014 [68]). All of these studies show the overlapping of legal norms of several distinct departments for just one resource such as fisheries. For example, in Zimbabwe, five departments have completely uncoordinated regulations on this resource [68]). Research from Zambia, Cameroon, Tanzania and Botswana shows similar findings [29].

Interestingly, these issues are not directly dealt with in the literature. Rather, the debate focuses on the "formal-informal" dichotomy or "bureaucratic and embedded" discussion, in which the argument is put forward that the distinction between formal institutions and informal norms cannot be the basis of an adequate analysis (see Cleaver 2003) [69]. However, I argue that this position misses the point because it does not reflect the relationship between historical change up to the present day, including the impact of the legal fragmentations as well as the ecological misreading of the landscape and the way social-ecological systems relate to each other (Berkes 1999 [70] makes a similar argument). Therefore, there is informality in so-called formal systems and formal processes in what are labelled informal and embedded customary systems. These contribute to institutional and legal pluralism from which actors can select based on the power constellations they find themselves in. One could, like Benjaminsen and Lund [46], critically argue that formal (and informal) colonial rule was not well enforced everywhere. That might be partially correct. Nevertheless, the new legal and formal administrative rules added up to the pluralism, even if it is not well enforced. They also provided ideological spheres of reference and can still now be strategically used by many actors. 


\section{The Presence and Absence of the State}

The previous section illustrated how the precolonial emic view on land interlinked with common-pool resources in the AFWeP cases has been disconnected during colonial and postcolonial times and has led to new institutional pluralism. This section further tries to understand today's land issues by linking them to the states in crisis phenomenon as a further act in this drama. While being at the centre of resource management, the African states researched in the AFWeP case studies, are new forms of territorial, fiscal and resource management entities that are often still in close contact with and dependent on the former colonial powers. Increasingly, they are also subscribing to international and global economic trade networks, which further influence the management of natural resources since these relationships produce much-needed foreign exchange that is needed to meet state infrastructure and social expenditures. The new, post-independence African states examined in the comparative AFWeP project were trying to continue with the raw material export-oriented structures they inherited from the colonizers. In all of the cases studied, states depended on one or two basic resources for cash and foreign exchange revenues. In doing so, they were trying for finance what the elites in power saw as the economic basis for financing imports in order to modernize the countries. Large infrastructure buildings and services (e.g., road networks, dams, large plantations, green revolution and agrarian subsidies) were being set up and were often financed with overseas loans with the anticipation of high revenues in the future. Between 1975 and 2000 changes in relative prices, such as increases in oil prices (imports) and decreases in the prices of other raw materials (e.g., metals, food and fibre cash crops for export) led to financial crises and weak state structures as staff salaries and infrastructure could no longer be financed.

Governments were thus soon in the position where "making a state" became expensive, while at the same time, state activities could not contribute to the project of modernization (see also Ferguson's book Expectations of Modernity 1999) [5]. Four out of five country studies in the AFWeP show that between the 1970s and 1990s a dismantling of the state, which had formally taken over the management of all the natural resources in the name of state property, took place. Botswana was the exception as its gains from diamond mining could be widely distributed. However, in all five countries the state had crafted huge plural complex and disconnected management systems with laws and regulations. However, due to the lack of finance, governments were financially unable to "make state". State institutions responsible for the management of all the disconnected resources could not be enforced. In most of the AFWeP cases studied, this led to de facto open access to common-pool resources.

Once again, the Kafue Flats fisheries plainly illustrate this. As many people working in the mines and in mining towns lost their jobs due to the copper price crash of 1975, they turned to fisheries in the hinterlands, such as the Kafue Flats, because fish fetched high prices in the urban centres. As the Zambian fishery department was underfinanced, understaffed and underequipped it was unable to enforce basic issues such as mesh size and closing times in the Kafue Flats. Many seasonal fishermen and fish traders (men and women) moved-and still move-to the flats. There they fish as they please, for example using fine meshed draw nets. However, the state is not only absent; in certain discourses it appears that it is also very present. For example, when local people complain to the commercial fishermen that they are unable to enforce their fishery institutions due their lack of power, the commercial fishermen refer to the fisheries as a national resource and that they, as citizens of the state, are entitled to fish this state resource. The state is thus present and absent at the same time: Absent because the state regulations are not enforced and present through the ideology of citizenship which is used as a source of legitimacy to get free access to the common-pool resource. Actors from outside the area thus increase their bargaining power in order to select the institutional setting that suits them best—de facto open access—by legalizing this choice based on the discourse of citizenship [30,50].

Similarly, powerful actors from outside the communities studied in Mali (outside fishermen), Tanzania (in-migrating peasants) and Cameroon (pastoralists through paying state taxes and immigrated peasants) choose citizenship as a statement of legitimacy to increase their bargaining power and in order to be able to select the institution which suits their economic interests best from the institutional 
diversity that exists. The notion of citizenship in Botswana is less important and the pressure to use common-pool resources is not as strong as in the other cases studied. In the case of the panhandle and Okavango delta, however, local people struggle over the notion of autochthony regarding the possibility to draft management plans for Community Based Natural Resource Management (CBNRM) schemes (see Saum 2010) [71].

Thus, in these cases the competing forms of institutions are a central reality as also shown by research on the issue of how land and belonging are interlinked (see Benjaminsen and Lund eds. 2003 [39], Derman et al. eds. 2007 [48], Kuba and Lenz eds. 2006 [47]). These authors refer to the notion of how identity is built and constructed in relation to state institutions, scarcity issues and the relationship between first-comers "and late-comers". Nevertheless, it is important to see how, in the context of state failure and legal pluralism, bargaining power between actors is distributed and particular institutional choices are strategically made and legitimized in a concrete setting, based on economic and political options and preferences. These options and preferences are relational and also depend on fluctuations in prices. Therefore, the new institutionalism model of Ensminger (1992) [43] tries to analyse how the basis of actors' bargaining power is influenced by changes in relative prices and also how it is influenced by ideologies and discourses to legitimate the selection of institutions such as for example the preference of private property over common property. An often-used obvious ideological dichotomy is the one between "modernity" and "tradition" $[29,30]$, which is similar to Ferguson's "cosmopolitan" and "local" (Ferguson 1999) [5]. The discourse of modern development often justifies state or private property while the discourse of traditional way of life legitimizes the claim on common property [29,30]. The Ensminger model of institutional change [43] and the check of chosen institutions on their robustness regarding resource use (Ostrom 1990) [36] give an indication on the ecological outcome of common-pool resources depending on distribution between and further behaviour of actors (see graph 1 from Ensminger [43]).

The model of Ensminger also hints at an important element of change, which triggers many local changes: External factors transform the relative prices for resources as commodities as well as for the value of an area compared to other commodities or areas (i.e., fish for trade shows a higher price increase as labour, an area close to a river under the context of increase of agrarian prices becomes more valuable for irrigation if infrastructure as a road is build). This change impacts the way that bargaining power of local actors as well as their options and selection of institution are shaped; at this stage there is a need to identify the triggering factors in this interactive process. I would argue that changes in relative prices are one of the strongest factors bringing about change. This is the case especially in the context of global neoliberal policies with which Africa is confronted.

\section{Paradoxes of Neoliberalism}

James Ferguson's work on neoliberalism in Africa outlined in the book Global Shadows (2006) [72] illustrates the issue of a policy that tries to cut state costs by delegating management of activities to the market and to lower levels of action arenas under the state and into the private sectors. This strategy seemed to be a central remedy to cope with state debts all over the continent as well as elsewhere, e.g., in Europe. And herein lies the paradox of neoliberalism: The idea of the state that ever since colonial times had been the vessel for protecting capitalism, now seems to be too expensive to maintain and needs a cure based on the medicine of dismantling the state. In relation to Africa, the discourse of efficiency (see Ferguson 2006) [72] also develops in the direction of restructuring the state and state services as these seem to be too costly. Internalized hegemonic discourses on the waste of financial resources, on corruption of elites, and on mismanagement and inefficiency in formal legal processes merge with the notion of the state, which is a naturalized colonial construct to be changed in neoliberal ways. However, as Harvey (2005) [11] points out from a Neo-Marxist perspective, neoliberalism can be seen as a political process of "accumulation by dispossession" by which the state reduces its legal capacities and controls, which then favours the economically and politically strong elites as it creates cheap spaces for their manoeuvrings. This process of neoliberalism is highly debated in historical 
social anthropology and critical geography, such as Wacquant (2009) [73] arguing that the neoliberal state is a political project which re-engineers the state and strengthens its penal element. This again has to be looked at from a theoretical (formal) and practical (informal) angle, as Hilgers (2012) [74] points out, and obtains its legitimacy from the discourse of globalization, which leads to localization practices (Swyngedouw, E. (2000) [75]). This process again hides the fact that the state still encompasses its citizens but frees itself from its duties (Ferguson and Gupta 2002) [76] as it comes under economic pressure (see Lobao, L., Martin, R., \& Rodríguez-Pose, A. (2009) [77]). But these powerful actors still need the state because the state is the body that restructures the legal order to create what I would call open opportunities. At the same time, the state provides a security-net for powerful market actors and provides legitimacy for their actions, arguing that all actions are made in the name of a democratic state. To marry Ferguson and Harvey on this point, the neoliberal order in Africa helped to distribute the scarce means into fewer hands by delegating more power to the local level on the front stage, while backstage, elites are profiting (see also Pootete and Ribot 2011 [78]). This is a new form of indirect rule by which the state remains the owner of the resources but does not bear transaction costs of their management, which are delegated to the local level. This is masked by the discourse of the incapacity of the government, in terms of state structures, to provide services and that the market will do this much better. Internationally, this discourse received high support, arguing it will give governance options to the lower level, itself an issue that many critical voices from development studies have been advocating for a long time. So, there is an ideological win-win situation-efficiency and the moral legitimacy of local participation, acting itself as an Anti-Politics Machine.

An example from the wildlife sector in Zambia is illustrative. While conservation and protection of wildlife had been a cornerstone of statehood, it became a major expenditure burden which could not be upheld after the neoliberal turn from the socialist system under Kenneth Kaunda to the market-oriented system of Fredrik Chiluba in the 1990s. The Wildlife Department, a military-like state organization, was then transferred into a so-called "Wildlife Authority", exposed to partial self-funding and asked to develop business models, in which tourism sites and lodges in the national parks had to be sold to foreign companies. This move was based on the obvious inefficiency of the Wildlife Department because of a lack of funds and increasing prices for wildlife products during the copper crisis when state income fell. As with the fisheries, the economic downturn led to de facto open access to state-managed common-pool resources. Due to high prices, pressure from local and outside communities on wildlife resources as well as from big business for trophy hunting increased [30,79]. Now that the Wildlife Authority has sold lodges to international operators, there are less revenues for the state as market forces are now responsible for the management of wildlife. In line with the efficiency and moral legitimacy discourse, protected areas have become an investment ground for conservation NGOs who, under the label of participatory approaches, have started the process of so-called "green grabbing" since profits from tourism and trophy hunting do not really trickle down to local or state levels but are in private hands (see also Fairhead, Leach and Scoones 2012 [17]). This is happening on territories that had already been grabbed from local people during colonial and again during postcolonial times that contain critical common-pool resources such as pasture, fisheries and wildlife as well as veld products (see Haller 2013 [30]). Chabwela and Haller 2010 [79]) provide a detailed analysis of institutional change from precolonial to postcolonial wildlife management illustrating this process.

The general argument here is not that the state did better but that by claiming to improve and decentralize resource governance, a small group of actors are now profiting by legitimizing this institutional choice through the discourse of efficiency and moral legitimacy. To increase moral legitimacy, participatory initiatives are linked to development issues. In reality, however, these initiatives and projects are more about elite control than local control and decentralization of power (see also Ribot et al., 2006 [80], Brockington, Igoe and Duffy 2008 [81], Galvin and Haller eds. 2008 [82]). While people will participate in monitoring and sanctioning devices in the wildlife sectors, there are no tangible benefits and no real ownership rights to resources that had been alienated by the state during colonial times and still, in the last instance, remain state property. Not just in Zambia but 
elsewhere in the AFWeP study as well as in the literature (see Haller and Galvin 2011 [82], Poteete and Ribot 2013 [78]), decentralization of wildlife and other common-pool resources such as timber for charcoal production is not about delegating power to the local level. On the contrary, it is about following the aims of - paradoxically—a cheaper way of recentralizing governance by externalizing several transaction costs (e.g., in community monitoring projects) to the local level (ibid, see also Faye 2014) [83].

Returning to land tenure issues, the basic turn came with legal procedures that liberalized land laws in Africa. Based on the notion that land tenure is insecure and thus no asset for secure investments, the World Bank and other trade organizations pushed the revision of land tenure rights in many African countries. This happened before large scale land acquisitions or Land Grabbing became an issue around 2007-2008. However, the idea based on de Soto's notion that a cheap and smart legal system for land or leasehold titles would provide enough security needed for investment and development became the paradigm to follow. In this legal discourse, investors are said "to be attracted" and will provide jobs and related benefits, leading ultimately to "development". The outcome of such processes is mixed.

Overviews by Wily (2003) [84] and Toulmin (2008) [47] point out some of the problems and show two major tendencies. In some areas, village titles provide a large part of land to a collective and, although driven by elites, they offer much better options for local governance (see for Rufiji Floodplain Tanzania Haller et al., 2013 [45]), while the other form opens avenues for private titles, be these titles for sale or leasehold titles for 40 to 99 years (for example in Pangani Floodplain in Tanzania Mbeyale 2010 [85] and the Kafue Flats Haller 2013 [30]). In this context one could argue that neoliberalism provides at least some gains to local people as their land rights are registered and acknowledged. But the issue is actually more complicated and exposes one of the paradoxes of neoliberalism. This form of decentralized recognition does not address social structures and power asymmetries in social settings, and thus privatized land can be lost due to low power and low economic capacities whereby poor landowners sell land and, therefore, their resource base. In addition, village land can be grabbed from the state by formalisation processes, creating zones on which the state has access for conservation and investments (see Bluwstein et al., 2018 [86]).

A number of examples can be used to illustrate this. As Toulmin points out [47], one needs to determine who the local owners are, which is not an easy task. As shown above, there are complicated histories of settlement and of competing rights and institutions to regulate the access of different actors and actors' groups to several resources during different times of the year (i.e., seasonality). Toulmin labels this the problem of the so-called secondary users, who lose access to many resources [47]. I will illustrate the issue with examples from Sierra Leone and Zambia.

In Sierra Leone, a large Swiss Company called ADDAX plans to develop sugarcane plantations with the aim of producing bioethanol. One of the policies regarded as best practice is that local landowners are compensated. There are indeed first-comer families among the Temne ethnic group who argue they were the first people in the area, while the late-comers were given land to use. The first-comer families, therefore, regard themselves as managers of the complex resource systems of forests and palm trees to which others (late-comers) had access based on an allocation process and on institutional settings of resource use. This access is based on a rotation system and rules for gathering wild fruits from palm trees or access to water as a common-pool resource. In this case there were common property-like institutions that regulated the access for members of a village, specifically of first- and late-comers. The government and ADDAX now tried to find out who the "land owners" were and created compensation payments for the land they "lease" from the first-comer groups, who were then labelled exclusive land owners without sharing obligations. While there is still land available, the best land has already been taken by ADDAX based on these leases. In addition, there are fruit trees on the land that has been given away, to which access is no longer possible, with only the first-comers get cash compensation for these losses (see Marfurt et al., 2016) [87]. The second case again illustrates the situation in Kafue Flats, where-based on a new land act - the president and local chiefs can give out leasehold titles for 99 years within a chief's territory. When such lands were to be allocated in the 
best pastures in the Kafue Flats, opposition to the procedure surfaced and created great conflicts as the powerful rich cattle owners as well as the less powerful actors with smaller numbers of cattle both were about to lose access to pastoral areas (Haller 2013) [30].

The paradox of a neoliberal order is to reduce state power while at the same time increasing state power by providing tools on all levels for elites to appropriate resources. And as power structures at local levels have transformed much since colonial times, powerful actors use whatever institution and legitimacy is available to profit from this change. Land managers in Sierra Leone thus have no problem to be seen as "traditional land owners", while chiefs in Zambia label themselves as "traditional authority" and therefore become the main actors when it comes to decisions on leasehold titles. This is then often done over the head of the people (see the title of a paper by Cotula, Vermeulen, Mathieu and Toulmin 2011) [88]. However, what is not recognized is the fact that this is based on neoliberal processes that took place before external land investments began to surface. It is then that the impact of the neoliberal order unfolds on land as an isolated resource: When a rise in relative prices has been experienced, it attracts not only foreign but also local investment. I argue that these investments are undermining local livelihoods as access to land related common-pool resources is fragmented. At the same time the "expectations of modernity" do not come true as there are few jobs and less income, while subsistence crop production and access to the commons is restricted and becomes impossible.

\section{Commons Grabbing or What Is Wrong with Land Grabbing?}

As I have tried to show in this paper, the land grabbing issue falls on already previous alienations and transformations of African tenure systems in colonial and postcolonial times, leading to pluralism, disconnections and fragmentations, which already removes the commons from people. However, I would argue that the negative effects of these processes have worsened during times of land grabbing. This is because existing asymmetries are strengthened and new ones are created as many households lose access to common-pool resources as a buffer that is important during times of crisis, while having to take higher risks in normal times to be able to make a livelihood. It is also a process in which new information technologies and formal urban knowledge represents a cutting edge, while a rural orientation loses its value and power. My main point is that in this context the label land grabbing is misleading as are large-scale land acquisitions and investments. What takes place is a process of primitive accumulation, but in a much stronger sense than originally thought of by Marx and Harvey. Studies show that despite familiar arguments advocating that common-pool resources are not so central for local livelihoods, they are, on the contrary, especially so in times of stress and crisis: The crisis that many households in Africa currently experience is already strong even without the issue of land appropriation by outsiders. Removing access to common-pool resources by undermining common property institutions leads to what we call here resilience grabbing. People struggle with the extremely high volatility of market prices for natural resources and with the stress of having to feed a family and obtain enough money to meet basic needs such as housing, education, clothing, the subsistence economy of many households is already undermined (see Haller 2003) [30]. In these cases, people try to diversify, often travelling long distances to earn money. While they are away from their home areas, their cultural landscapes can be destroyed or grabbed and common as well as adpative and transformative capacity [1] is removed from local people. This renders them (smallholders, women and the elderly) extremely vulnerable to additional stresses such as sickness, climate variability or what is labelled "climate change". It leads to a young generation of people who have no future perspective as they have lost membership of the commons and access to common-pool resources, even if they are well educated, as they do not belong to the elite. If we speak of commons grabbing leading to resilience grabbing, and not just land grabbing, the issues become clearer as it adopts the local perspective as also illustrated by an Ila agropastoral farmer on the Kafue Flats in relation to fisheries: 
"If I have a problem (financial) or not enough food, I go to the flats and get some fish! But now I cannot get fish anymore, because it is all taken away. Or there is sugarcane, a land-owner or a land for wild animals (protected area). So, I just go hungry!" (interview with author, December 2003, Mbeza, Kafue Flats, Zambia)

In the opinion of less powerful local people this process is undermining livelihood options as it restricts their access to a wide base of resources that are centrally important in times of need. Therefore, it is not just land that is taken away. Using the label of land grabbing or LSLA leads us into the trap of the anti-politics machine of development that does not match with local views.

\section{Where to Take It from Here}

The main argument in this article is, of course, at odds with the idea of a booming Africa with which I began this paper. It is instead the view of the doomed continent which is, of course, only one side of the story. The other side-and this is the answer to the question of where to take the debate-is to clearly analyse how local actors view this process, view the deals and conceptualize aspirations. It might well be that at the beginning of a land alienation or investment process, many local people hope for jobs and basic development facilities such as schools, health posts and secure water supplies and therefore might highly favour such an investment. But on the other hand, research shows that these promised developments do not come that easily and quickly, while access to vital resources is often lost immediately. It is interesting to see, then, what type of strategies and resistance local actors adopt in order to buffer the problem of the commons grabbing which in turn leads to resilience grabbing. This is then vested in strategies to change and devise their own institutions that might lead to a bricolage (Cleaver [57]) but also to a strategic selection of options based on bargaining power and possibilities within institutional pluralism through the strategy of institution shopping.

It will be important to study such processes and to discuss what the dominant strategies are to regain resilience via adaptation and transformability [1], using and maintaining cultural landscapes via common property institutions. Communal titles and mapping of resources, new discussions at the local level about institutions for the management of resources (e.g., by-laws, local conventions) might be an important way forward. I do not speak in favour of formalization but of true participation. Despite local political asymmetries, most actors would thus gain a sense of ownership of the institution-building process, a process which is called constitutionality. This term refers to processes of bottom-up institution building in which local actors, despite differences in power relations, find a way to get a sense of ownership in the crafting of institutions. Contrary to approaches such as environmentality (Agrawal 2005) [89], based on Foucault's governmentality transforming local actors into environmental subjects, a new approach called constitutionality is based on empirical studies of such processes and argues that real local participation anticipating power-asymmetries between actors and creativity for setting up rules addressing resource problems is the key to sustainability (see Haller et al., 2016 [90], 2018, [91]). Newer publications based on social anthropological research covering cases of impacts of European investments on land and related commons also show differentiated reactions to commons and resilience grabbing, reaching from small scale reactions ("weapons of the weak") to open resistance and bottom-up institution building (Haller, Breu, de Moor, Rohr and Znoj (eds.) 2019 [92], Haller et al 2019 [93].

Studying such processes can also lead to policy-driven ideas on how to support local resource users from commons grabbing and to strengthen resilience of their livelihoods and their cultural landscape ecosystems.

Funding: The AFWeP-Project was funded by the Swiss National Science Foundation (SNSF), the Swiss Development Corporation via the National Competence Centre in Research (NCCR) North-South (2002-2010), literature research was part of the SNSF grant Nr. 10001A_152773). The APC was funded by the Swiss National Science Foundation.

Conflicts of Interest: The authors declare no conflict of interest. 


\section{References}

1. Folke, C.; Carpenter, S.; Walker, B.; Scheffer, M.; Chapin, T.; Rockström, J. Resilience thinking: Integrating resilience, adaptability and transformability. Ecol. Soc. 2010, 15. [CrossRef]

2. Robbins, P. Political Ecology: A Critical Introduction; Malden Blackwell Publishing Inc.: Oxford, UK, 2005.

3. Peet, R.; Robbins, P.; Watts, M. (Eds.) Global Political Ecology; Routledge: London, UK, 2010.

4. Ferguson, J. The Anti-Politics Machine: "Development" and Bureaucratic Power in Lesotho; University of Minnesota Press: Minneapolis, MN, USA, 1994.

5. Ferguson, J. Expectations of Modernity: Myths and Meanings of Urban life on the Zambian Copperbelt; University of California Press: Pasadena, CA, USA, 1999; Volume 57.

6. Robertson, C. The Fastest Billion: The Story Behind Africa's Economic Revolution; Renaissance Capital: London, UK, 2012.

7. Deininger, K. Challenges Posed by the New Wave of Farmland Investment. J. Peasant Stud. 2011, 38, $217-248$. [CrossRef]

8. De Schutter, O. How not to think of Land Grabbing: Three Critiques of Large Scale Investments in Farmland. J. Peasant Stud. 2011, 38, 249-280. [CrossRef]

9. Hall, R. Land grabbing in Southern Africa: The many faces of the investor rush. Rev. Afr. Political Econ. 2011, 38, 193-214. [CrossRef]

10. Cotula, L. The Great African Land Grab: Agricultural Investments and the Global Food System; Zed Books Ltd.: London, UK, 2013.

11. Harvey, D. A Brief History of Neoliberalism; Oxford University Press: Oxford, UK, 2015.

12. Basu, P.K. The Political Economy of Land Grab. Econ. Political Wkly. 2007, 42.

13. Oya, C. Methodological Reflections on 'Land Grab' Databases and the 'Land Grab' Literature 'Rush'. J. Peasant Stud. 2013, 40, 503-520. [CrossRef]

14. Lanz, K.; Gerber, J.D.; Haller, T. Land Grabbing, the State and Chiefs: The Politics of Extending Commercial Agriculture in Ghana. Dev. Chang. 2018, 49, 1526-1552. [CrossRef]

15. German, L.; Schoneveld, G.; Pacheco, P. The social and environmental impacts of biofuel feedstock cultivation: Evidence from multi-site research in the forest frontier. Ecol. Soc. 2011, 16. [CrossRef]

16. Li, T.M. Centering Labor in the Land Grab Debate. J. Peasant Stud. 2011, 38, 281-298. [CrossRef]

17. Fairhead, J.; Leach, M.; Scoones, I. Green Grabbing: A New Appropriation of Nature? J. Peasant Stud. 2012, 39, 237-261. [CrossRef]

18. Locher, M.; Sulle, E. Challenges and Methodological Flaws in Reporting the Global Land Rush: Observations from Tanzania. J. Peasant Stud. 2014, 41, 569-592. [CrossRef]

19. Wolf, E.R. Europe and the People without History; University of California Press: Pasadena, CA, USA, 2010.

20. Stocks, A. Too Much for Too Few: Problems of Indigenous Land Rights in Latin. Annu. Rev. Anthr. 2005, 34, 85-104. [CrossRef]

21. Chanock, M. Paradigms, Policies and Property: A Review of the Customary Law of Land Tenure. In Law in Colonial Africa; James Currey: London, UK, 1991; pp. 61-84.

22. Peters, P. Conflicts over Land and Threats to Customary Tenure in Africa. Afr. Aff. 2013, 1, 1-20. [CrossRef]

23. Millington, A.C. Creating Coca Frontiers And cocaleros in Chapare, Bolivia, 1940-1990. In The Origins of Cocaine; Gootenberg, P., Dávalos, L., Eds.; Routledge: London, UK, 2018; pp. 84-113.

24. Bodley, J.H. Victims of Progress; Rowman \& Littlefield: New York, NY, USA, 2014.

25. Geiger, D. (Ed.) Frontier Encounters: Indigenous Communities and Settlers in Asia and Latin America; IWGIA Document No. 120; International Work Group for Indigenous Affairs: Copenhagen, Denmark, 2008.

26. Li, T.M. Land's End: Capitalist Relations on an Indigenous Frontier; Duke University Press: Durham, NC, USA, 2014.

27. Galvin, M.; Haller, T. (Eds.) People, Protected Areas and Global Change: Participatory Conservation in Latin America, Africa, Asia and Europe; Perspectives of the Swiss National Centre of Competence in Research (NCCR) North-South; University of Bern, Geographica Bernensia, 3: Bern, Switzerland, 2008.

28. Mamdani, M. Citizen and Subject: Contemporary Africa and the Legacy of Late Colonialism; Princeton Studies in Culture/Power/History; Princeton University Press: Princeton, NJ, USA, 1996.

29. Haller, T. (Ed.) Disputing the Floodplains: Institutional Change and the Politics of Resource Management in African Floodplains; Brill: Leiden, The Netherlands, 2010. 
30. Haller, T. The Contested Floodplain: Institutional Change of the Commons in the Kafue Flats, Zambia; Lexington (Rowman \& Littlefield): Lenham, UK, 2013.

31. Firmin-Sellers, K. Institutions, context, and outcomes: Explaining French and British rule in West Africa. Comp. Politics 2000, 253-272. [CrossRef]

32. Netting, R.M. Smallholders, Householders: Farm Families and the Ecology of Intensive, Sustainable Agriculture; Stanford University Press: Stanford, CA, USA, 1993.

33. Neumann, R.P. Imposing Wilderness. Struggles over Livelihood and Nature Preservation in Africa; University of California Press: Berkley, CA, USA, 1998.

34. Hardin, G. The tragedy of the commons. Science 1968, 162, 1243-1248. [PubMed]

35. Acheson, J. Management of Common Property Resources. In Economic Anthropology; Plattner, S., Ed.; Stanford University Press: Stanford, CA, USA, 1989; pp. 351-378.

36. Ostrom, E. Governing the Commons. The Evolution of Institutions for Collective Action; Cambridge University Press: Cambridge, UK, 1990.

37. Haller, T. Understanding Institutions and their Links to Resource Management from the Perspective of New Institutionalism; NCCR North-South Dialogue 2: Bern, Switzerland, 2007.

38. Feeney, D.; Berkes, F.; McCay, J.B.; Acheson, M.J. The Tragedy of the Commons: Twenty-Two Years Later. Hum. Ecol. 1990, 18, 1-19. [CrossRef]

39. Fairhead, J.; Leach, M. Misreading the African Landscape. Society and Ecology in a Forest-Savannah Mosaic; Cambridge University Press: Cambridge, UK, 1996.

40. North, D. Institutions, Institutional Change and Economic Performance; Cambridge University Press: Cambridge, UK, 1990.

41. Haller, T. Is there a Culture of Sustainability? What Social and Cultural Anthropology has to offer 15 years after Rio. In 15 Jahre nach Rio—Der Nachhaltigkeitsdiskurs in den Geistes—und Sozialwissenschaften: Perspektiven —Leistungen—Defizite; Burger, P., Kaufmann-Hayoz, R., Eds.; Schweizerische Akademie der Geistes—und Sozialwissenschaften: Bern, Switzerland, 2007; pp. 329-356.

42. Haller, T. Institutional Change, Power and Conflicts in the Management of Common-Pool Resources in African Floodplain Ecosystems: An Introduction. In Disputing the Floodplains: Institutional Change and the Politics of Resource Management in African Wetlands; African Social Studies Series; Haller, T., Ed.; Brill: Leiden, The Netherlands, 2010; pp. 1-78.

43. Ensminger, J. Making a Market. The Institutional Transformation of an African Society; Cambridge University Press: Cambridge, UK, 1992.

44. Williamson, O.E. Transaction Cost Economics. In Handbook of Industrial Organization; Elsevier: Amsterdam, The Netherlands, 1989; Volume 1, pp. 135-182.

45. Haller, T.; Fokou, G.; Mbeyale, G.; Meroka, P. How fit turns into misfit and back: Institutional transformations of pastoral commons in African floodplains. Ecol. Soc. 2013, 18, 34. [CrossRef]

46. Benjaminsen, T.A.; Lund, C. (Eds.) Securing Land Rights in Africa; Frank Cass: London, UK; Portland, OR, USA, 2003.

47. Toulmin, C. Securing Land and Property Rights in Sub-Saharan Africa: The Role of Local Institutions. Land Use Policy 2008, 26, 10-19. [CrossRef]

48. Haller, T. Towards a New Institutional Political Ecology. In The Commons in a Glocal World; Haller, T., Breu, T., de Moor, T., Rohr, C., Znoj, H.P., Eds.; Routledge: London, UK, 2019; pp. 90-120.

49. Lenz, K. Land and the Politics of Belonging. An Introduction. In Land and the Politics of Belonging; Kuba, R., Lenz, K., Eds.; Brill: Leiden, The Netherlands, 2006; pp. 1-34.

50. Haller, T.; Merten, S. “We are Zambians—don't tell us how to fish!" Institutional Change, Power Relations and Conflicts in the Kafue Flats Fisheries in Zambia. Hum. Ecol. 2008, 36, 699-715.

51. Haller, T.; Merten, S. "We had Cattle and did not Fish and Hunt Anyhow!" Institutional Change and Contested Commons in the Kafue Flats Floodplain (Zambia). In Disputing the Floodplains: Institutional Change and the Politics of Resource Management in African Floodplains; Haller, T., Ed.; Brill: Leiden, The Netherlands, 2010; pp. 301-360.

52. Fokou, G. Tax Payments, Democracy and Rent Seeking Administrators: Common-Pool Resource Managment, Power Relations and Conflicts among the Kotoko, Musgum, Fulbe and Arab Choa in the Waza Logone Floodplain (Cameroon). In Disputing the Floodplains: Institutional Change and the Politics of Resource Management in African Floodplains; Haller, T., Ed.; Brill: Leiden, The Netherlands, 2010; pp. 121-169. 
53. Meroka, P. Ujamaa-Policies, Open Access and Differential Collective Action: Common-Pool Resource Management, Institutional Change and Conflicts in the Rufiji Floodplain (Tanzania). In Disputing the Floodplains: Institutional Change and the Politics of Resource Management in African Floodplains; Haller, T., Ed.; Brill: Leiden, The Netherlands, 2010; pp. 245-300.

54. Kuba, R.; Lenz, K. (Eds.) Land and the Politics of Belonging; Brill: Leiden, The Netherlands, 2006.

55. Derman, B.; Odgaard, R.; Sjaastad, E. (Eds.) Conflicts over Land and Water in Africa; James Currey: Melton, UK, 2007; p. 256.

56. Chaveau, J.-P. How does an Institution Evolve? Land, Politics, Intergenerational Relations and the Institutions of the tutorat among Authochtones and Immigrants (Gnab region, Ivory Coast). In Land and the Politics of Belonging in West-Africa; Kuba, R., Lenz, C., Eds.; Brill: Leiden, The Netherlands, 2006; pp. 213-240.

57. Cleaver, F. Reinventing institutions: Bricolage and the social embeddedness of natural resource management. Eur. J. Dev. Res. 2002, 14, 11-30. [CrossRef]

58. Scott, J.C. Seeing Like a State: How Certain Schemes to Improve the Human Condition Have Failed; Yale University Press: New Haven, CT, USA, 1998.

59. Moorehead, R. Changes Taking Place in Common-Property Resource Management in the Inland Niger Delta of Mali. In Common Property Resources; Berkes, F., Ed.; Belhaven Press: London, UK, 1989; pp. 256-272.

60. Beeler, S.; Frei, K. Between Water Spritis and Market Forces: Institutional Change in the Niger Delta Fisheries among the Somono and the Bozo Fishermen of Wandiaka and Daga. Womina (Mali). In Disputing the Floodplains: Institutional Change and the Politics of Resource Management in African Floodplains; Haller, T., Ed.; Brill: Leiden, The Netherlands, 2010; pp. 77-120.

61. Berry, S. No Condition is Permanent: The Social Dynamics of Agrarian Change in Sub-Saharan Africa; University of Wisconsin Press: Madison, WI, USA, 1993.

62. Chanock, M. Law, Custom, and Social Order: The Colonial Experience in Malawi and Zambia; Cambridge University Press: Cambridge, UK, 1985.

63. Moor, S.F. Law as Process: An Anthropological Approach; LIT Verlag: Munster, Germany, 2000.

64. Meillassoux, C. Maidens, Meal and Money: Capitalism and the Domestic Economy; Cambridge University Press: Cambridge, UK, 1981.

65. Lenz, K. First-Comers and Late Comers: Indigenous Theories of Land Ownership in the West Afrcan Savanna. In Land and the Politics of Belonging; Kuba, R., Lenz, K., Eds.; Brill: Leiden, The Netherlands, 2006; pp. $34-57$.

66. Brockington, D. Fortress Conservation: The Preservation of the Mkomazi Game Reserve, Tanzania; James Currey: London, UK, 2002.

67. Meroka, P.; Haller, T. Government Wildlife, Unfulfilled Promises and Business: Lessons from Participatory Conservation in the Selous Game Reserve, Tanzania. In People, Protected Areas and Global Change; Galvin, M., Haller, T., Eds.; Geographica Bernensia: Bern, Switzerland, 2008; Volume 3, pp. 177-219.

68. Mhlanga, L.; Nyikahadozi, K.; Haller, T. (Eds.) Fragmentation of Natural Resources Management: Experiences from Lake Kariba; LIT Verlag: Berlin, Germany, 2014.

69. Cleaver, F. Reinventing Institutions: Bricolage and the Social Embeddedness of Natural Resource Management. In Securing Land Rights in Africa; Benjaminson, T.A., Lund, C., Eds.; Frank Cass: London, UK, 2003; pp. 11-30.

70. Berkes, F. Sacred Ecology. Traditional Ecological Knowledge, and Resource Management; Tylor \& Francis: Philadelphia, PA, USA, 1999.

71. Saum, R. Promise and reality of community based natural resourcem management in Botswana: Common-pool resource use and institutional change in Ikoga, Okovango Delta (Pandhandle). In Disputing the Floodplains: Institutional Change and the Politics of Resource Management in African Floodplains; Haller, T., Ed.; Brill: Leiden, The Netherlands, 2010; pp. 361-412.

72. Ferguson, J. Global Shadows: African in the Neoliberal World Order; Duke University Press: Durham, NC, USA, 2006.

73. Wacquant, L. Punishing the Poor: The Neoliberal Government of Social Insecurity; Duke University Press: Durham, NC, USA, 2009.

74. Hilgers, M. The historicity of the neoliberal state. Soc. Anthropol. 2012, 20, 80-94. [CrossRef]

75. Swyngedouw, E. Authoritarian governance, power, and the politics of rescaling. Env. Plan. D Soc. Space 2000, 18, 63-76. [CrossRef]

76. Ferguson, J.; Gupta, A. Spatializing states: Toward an ethnography of neoliberal governmentality. Am. Ethnol. 2002, 29, 981-1002. [CrossRef] 
77. Lobao, L.; Martin, R.; Rodríguez-Pose, A. Rescaling the state: New modes of institutional-territorial organization. Camb. J. Reg. Econ. Soc. 2009, 2, 3-12. [CrossRef]

78. Poteete, A.R.; Ribot, J.C. Repertoires of Domination: Decentralization as Process in Botswana and Senegal'. World Dev. 2011, 39, 439-449. [CrossRef]

79. Chabwela, H.; Haller, T. Governance issues, potentials and failures of participatory collective action in the Kafue Flats, Zambia. Int. J. Commons 2010, 4, 621-642. [CrossRef]

80. Ribot, J.C.; Agrawal, A.; Larson, A.M. Recentralizing while decentralizing: How national governments reappropriate forest resources. World Dev. 2006, 34, 1864-1886. [CrossRef]

81. Brockington, D.; Duffy, R.; Igoe, J. Nature Unbound: The Past, Present and Future of Protected Areas; Earthscan: London, UK, 2008.

82. Haller, T.; Galvin, M. Challenges for Participatory Conservation in Times of Global Change: Lessons from a Comparative Analysis and New Developments. In Research for Sustainable Development: Foundations, Experiences, and Perspectives. Perspectives of the Swiss National Centre of Competence in Research (NCCR) North-South; Wiesmann, U., Hurni, H., Eds.; University of Bern, Geographica Bernensia: Bern, Switzerland, 2011; Volume 6, pp. 467-503.

83. Faye, P. Democratizing Forestry: Decentralization and Constitutionality in two Interventions in Senegal. Doctoral dissertation submitted to the Faculty of Philosophy and Humanities of the University of Bern, in partial fulfilment of the requirements for the degree of Doctor of Social Anthropology. Ph.D. Thesis, University of Bern, Bern, Switzerland, 25 September 2014.

84. Wily, L.A. Community-based land tenure management: Questions and answers about Tanzania's new Village Land Act, 1999. International Institute for Environment and Development. 2003. Available online: http://repository.out.ac.tz/1641/1/9295I_community_based_land_tenure.pdf (accessed on 10 October 2012).

85. Mbeyale, G. From Integrated Slope Management to Fragmented Use: Common-Pool Resources, Institutional Change, and Conflicts in Pangani River Basin, of Same District (Tanzania)'. In Disputing the Floodplains: Institutional Change and the Politics of Resource Management in African Floodplains; Haller, T., Ed.; Brill: Leiden, The Netherland, 2010; pp. 194-244.

86. Bluwstein, J.; Lund, J.F.; Askew, K.; Stein, H.; Noe, C.; Odgaard, R.; Magana, F.; Engström, L. Between dependence and deprivation: The interlocking nature of land alienation in Tanzania. J. Agrar. Chang. 2018, 18, 806-830. [CrossRef]

87. Marfurt, F.; Käser, F.; Lustenberger, S. Local Perceptions and Vertical Perspectives of a Large Scale Land Acquisition Project in Northern Sierra Leone. Homo Oeconomicus 2016, 1-19. [CrossRef]

88. Cotula, L.; Vermeulen, S.; Mathieu, P.; Toulmin, C. Agricultural investment and international land deals: Evidence from a multi-country study in Africa. Food Secur. 2011, 3, 99-113. [CrossRef]

89. Agrawal, A. Environmentality, Technologies of Government and the Making of Subjects; Yale University Press: New Haven, CT, USA, 2005.

90. Haller, T.; Acciaioli, G.; Rist, S. Constitutionality: Conditions for Crafting Local Ownership of Institution-Building Processes. Soc. Nat. Resour. 2016, 29, 68-87. [CrossRef]

91. Haller, T.; Belsky, J.M.; Rist, S. The Constitutionality Approach: Conditions, Opportunities, and Challenges for Bottom-Up Institution Building. Hum. Ecol. 2018, 46, 1-2. [CrossRef]

92. Haller, T.; Breu, T.; De Moor, T.; Rohr, C.; Znoj, H. (Eds.) The Commons in a Glocal World: Global Connections and Local Responses; Routledge: Abingdon, UK, 2019.

93. Haller, T.; Adams, T.; Gmür, D.; Käser, F.; Lanz, K.; Marfurt, F.; Schubiger, E.; von Sury, A.; Gerber, J.D. Large-Scale Land Acquisition as Commons Grabbing: A Comparative Analysis of Six African Case Studies. In Global Perspectives on Long Term Community Resource Management; Springer: Cham, Switzerland, 2019; pp. 125-164.

(C) 2019 by the author. Licensee MDPI, Basel, Switzerland. This article is an open access article distributed under the terms and conditions of the Creative Commons Attribution (CC BY) license (http://creativecommons.org/licenses/by/4.0/). 